\title{
The impact of institutions, law and corruption in business environment - Evidence for Kosovo
}

\author{
Jeton Zogjani \\ The Staffordshire University, UK \\ The University of Prishtina, Kosovo \\ Majlinda Mazelliu \\ The Staffordshire University, UK \\ Baton Humolli \\ The University of Prishtina, Kosovo \\ Vesa Qehaja \\ The University of Prishtina, Kosovo \\ Artan Kunushevci \\ The University of Prishtina, Kosovo
}

\begin{abstract}
Business environment across different time periods of transition is challenged from different implications, such as: political and institutional instability, inadequate laws and corruption steadily and continuously increasing in transition countries. The main overview of research paper is focused in process of reforms and priority in business environment in transition countries. Then is identify the main obstacles and difficulties that business environment is faced in Kosovo and in detail is presented the reforms that are made from Kosovo institutions in business environment over the past few years. Through OLS method are analyzed separately three main areas that are included in research paper (institutions, law and corruption in business environment). The results have shown that institutions (through business policies) have positive impact on business environment, but political stability in Kosovo has negative impact in business environment. In analysis between law and business environment is appeared that role of law has negative impact in business environment, but protecting investors (through law) has shown positive impact in business environment. In the third analysis of corruption both variables (corruption and bribery) have shown positive impact in business environment in Kosovo. Kosovo should establish sustainable institutions, enforce the law and to reduce drastically the corruption, these are the main priority for a stable business environment. Furthermore, Kosovo should continue to improve the process of reforms in order to create a favorable business environment (such is in developed countries).
\end{abstract}

Keywords: bribery costs, business climate, regression method, political stability, protecting investors

\section{INTRODUCTION}

Development of business environment in transition economies is the most important issues for transformation of the planned economy to the market economy thus, the quality of reforms and stability in the business environment can reflect directly to economic growth and poverty 
reduction in these countries, (Steves et al, 2004). As the key important aspect for business environment is to allow the private entrepreneurship to flourish in transition economies, (Fankhauser, 2005). Despite of many opportunities that business environment has had in Kosovo, it was closely related with the lack of competition (in some sectors), (EB Report, 2013). According to (World Bank Report, 2015), in recent years Kosovo has improved the institutional and legal framework for reinforcing the necessary foundations in business environment. In the other side, business environment in Kosovo is challenged with lot of difficulties in context of doing business (particularly on construction permits and enforcing contracts) and also entrepreneurs in Kosovo are faced with lot of obstacles in their business environment, such as: crime, corruption, and access to electricity, (EBRD Report, 2011). However, the policy makers in Kosovo are trying to approve regulations for business environment through ongoing reforms and priority to improve business environment like in developed countries, (World Bank Report, 2016).

\section{LITERATURE REVIEW}

Process of transformation for transition economies has been very protracted, also the process of reforms in business environment (competition policy, privatization and enterprise restructuring) often are faced with lot of difficulties and opposition from political interests or from vested interests of certain groups, (Roaf et al, 2013). In many transition countries, strengthening of law should be as main priority, because lack enforcement of the law in business environment in these countries is the biggest concern, (Anderson \& Gray, 2007). In addition, as a bigger obstacle in business environment across transition economies is an informal payment (through corruption and bribery), (Anderson \& Shimul, 2013). Thus, corruption together with high taxes and inappropriate law (in taxes) are classified as bigger obstacles in business environment, particularly for Western Balkan countries (WBCs), (Džafić, 2014). But, in other side mostly of transition countries have started their crucial reforms in institution and in legal system, it is essential for providing sustainability in entrepreneurship and in the whole business environment in these countries, (Estrin et al, 2005).

Table 1 Overview of institution, law and corruption in business environment for WBCs

$$
\text { Political Stability* Role of Law* Corruption Index Doing Business Report }
$$

$\begin{array}{lcccc}\text { Albania } & 0.06 & -0.57 & 33 & 16.5 \\ \text { BiH } & -0.37 & -0.17 & 39 & 17.7 \\ \text { Croatia } & 0.61 & 0.26 & 48 & 11.1 \\ \text { Kosovo } & -0.98 & -0.57 & 33 & 15.8 \\ \text { Macedonia } & -0.37 & -0.20 & 45 & 5.1 \\ \text { Montenegro } & 0.49 & 0.02 & 42 & 12.8 \\ \text { Serbia } & -0.1 & -0.34 & 41 & 16.4\end{array}$

Note (*): political stability and role of law include data from 2013

Source: Worldwide Governance Indicators 2013, Transparency International Report 2015 \& World Bank 2015

According to (EC Report, 2014), business environment in Kosovo is improved over the past few years, but Kosovo should improve further conditions in business environment, such as: reducing institutional barriers, reduction of the informal economy and corruption, develop the 
financial market, etc. In context of institutional legislation in business environment, Kosovo was accompanied with lot of delays in aspect of licensing and permit services for businesses, (World Bank Report, 2011). For more, insufficient energy supply and the structural reforms in Kosovo are too far to complete business conditions and they still hamper to develop the private sector in business environment in Kosovo, (IMF Report, 2015). Then, according to (Council of Europe Report, 2016), corruption is the main obstacles in Kosovo business environment, it has achieved a broad extension in government procurement and to ensure a government contract from 2011 to 2014 business owners have to paid over $4 \%$ of contract value, it is higher than in 2009 (the contract value is paid $1 \%$ ). Moreover, Kosovo needs to strengthen its fight against corruption because Kosovo has high rate of corruption (the highest rate in the region) and business owners have lower tendency to perceive corruption in Kosovo, (Budak \& Rajh, 2011).

In other side, the institutions of Kosovo has established the National Council for Economic Development (NCED) and through NCED is made significant progress in approval the necessary reforms for creating appropriate conditions for business environment in Kosovo, also its impact was directly in business climate conditions, such as: simplify the procedures for business registration and on reducing registration costs, etc (World Bank Report, 2015). According to (IMF Report, 2015) in recent years the Kosovo institutions are effort constantly to improve the reforms in business environment (such as: protection of foreign investors, reduce the cost of doing business, financial and technical projects for support to SMEs, etc.) and these reforms have given their visible effect in improving Kosovo business environment in global ranking (Kosovo has made the biggest improve than other Western Balkan countries). As regard to improve further the investment climate in Kosovo, at first the Kosovo institutions should to improve its human resource (such as: vocational education and training) to fulfilled the needs of employers in labour market then should to determine the issues about property and land registers, (OECD Report, 2013).

Figure 1 Indicators of Business Environment in Kosovo

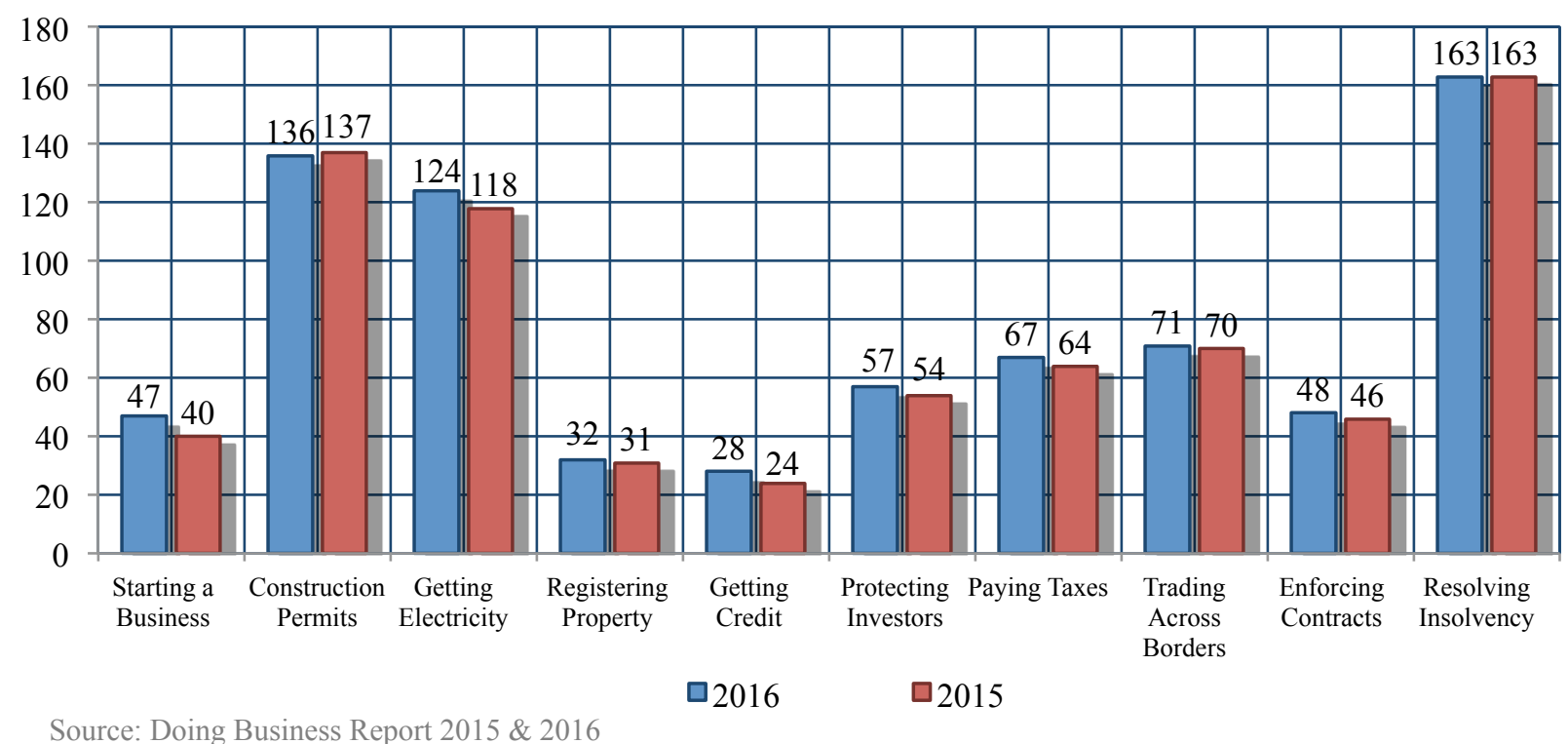

Despite of these obstacles and difficulties that business environment is challenged over the past few years; Kosovo institutions are commitment to improve reforms and competition in business environment, (MTI Report, 2011). Then, these commitments have affected mostly in reforms of doing business, such as: protecting investors and starting a business and Kosovo in 
2013 has improved their position in doing business indicators for over 25 positions in global ranking, (World Bank Report, 2012). Moreover, according to (World Bank Report, 2013) Kosovo is one of the few countries that are characterized with the most improved economy during 2014 and it is as results of elimination the minimum capital requirement and business registration fee for new businesses in Kosovo. The business environment in Kosovo (based on doing business indicators) has continued to improve in 2015 (approximately 6 position has improved than in 2014 in the world ranking) as well as Kosovo has achieved the European and regional average in doing business indicators, (World Bank Report, 2014). According to (World Bank Report, 2016) Kosovo has improved further its position in the global ranking in 2016 (see figure above) and reforms are focused mostly on construction permits (reducing the building permit fee) and paying taxes (abolishing the annual license fee).

\section{METHODOLOGY AND RESEARCH CONCEPTS}

In this section will explain about data collection and its limitations as well as will provide the structure of research methodology through definition of hypothesis, the main objectives of research and definition of variables for analysis (Kothari, 2004). The data for analysis are secondary data (quantitative) and they are collected from annual reports of international institutions (such as: World Bank and UNODC). Then, our limitations during the process of data collection are mostly based in the lack of important variables that we cannot find in international reports (such as: macroeconomics environment, public infrastructure, business and customer sophistication, innovation, juridical independence, etc) and they may have impact in analysis of business environment in Kosovo.

\section{Definition of hypothesis}

The research hypothesis is very important in research papers and hypothesis should be formulated and must be rigorously tested by using the appropriate methodology, (Phillips \& Pugh, 2005). The hypothesis of this research paper are: the most important variables of institutions (political stability) and law in Kosovo (role of law) have negative impact in business environment, but in other side corruption have positive impact in Kosovo business environment. Thus, in many literature and international reports have argued that corruption in Kosovo is one of three main obstacles in business environment, and then is identify that instability of (government) institutions and lack of law in transition countries are the main barriers in process of reforms in business environment.

\section{Research Objective and Research Questions}

Through objectives of research we can verify the facts, analyze the events, and to develop new concepts and scientific theories, (Rajasekar et al, 2006). The research objectives determine these issues: process of reforms and priorities, the main obstacle in business environment in transition economies (including Kosovo), then the main obstacles in Kosovo business environment, favorable reforms through Kosovo legislation (laws) and its effect in improving the business climate in the global ranking in the over past few years. The research questions help to articulate the intentions and perspectives that are involved directly in research paper, (Agee, 2009). Then, the main research question is focused in the impact of institutions, law and corruption in Kosovo business environment from 2011 - 2015. However, as the sub-questions of the research are:

1. How many is the impact of government institutions, law and corruption in Kosovo business environment? 
2. Which are main factors (or variables) in analyses that have the higher impact in Kosovo business environment over the past few years?

3. How many is the rate of determination and correlation between institutions, law and corruption in business environment in Kosovo?

\section{Definition of method for analysis and data analysis}

Regression analysis determines relationship between dependent and independent variables, also it provides analysis about prediction and impact of independent variables in dependent variable(s), (Campbell \& Campbell, 2008). Through regression method are analyzed separately variables of institutions, law and corruption in Kosovo business environment in period of time 2011 - 2015. Definition of regression equation for each analysis of institutions, law and corruption and their independent variables are as following:

The first analysis is about impact of institutions in business environment in Kosovo and the variables of institutions that are used in analysis are political stability and business policies (as independent variables) and business environment (as a dependent variable) in Kosovo. The analysis of regression methods is based on following equation.

$$
\operatorname{Ln}(B I t)=\beta 0+\beta 1 \ln (P S t)+\beta 2 \ln (B P t)+\varepsilon t
$$

where the main variables for analyses are as following:

* $\quad$ BE = Business Environment;

* PS = Political Stability;

* SB = Starting Business;

* $\quad \varepsilon \mathrm{t}=$ Standard Error;

* $\quad \beta 0, \beta 1, \beta 2$, are included in the analysis parameters;

In the second analysis, we have estimated the impact of Kosovo's law in business environment in Kosovo. The variables that are used in regression method are between independent variables of law (role of law and protecting investors) in Kosovo and dependent variables (business environment in Kosovo). In following equation is appeared the variables that are analysis through regression method:

$$
\operatorname{Ln}(B I t)=\beta 0+\beta 1 \ln (R L t)+\beta 2 \ln (P I t)+\varepsilon t
$$

where the main variables for analyses are as following:

* $\quad \mathrm{BE}=$ Business Environment;

* $\quad \mathrm{RL}=$ Role of Law;

* PI = Protecting Investors;

* $\quad \varepsilon \mathrm{t}=$ Standard Error;

* $\quad \beta 0, \beta 1, \beta 2$, are included in the analysis parameters;

In the third analysis is appeared the impact of corruption (variables) in business environment in Kosovo through regression method. The independent variables of corruption that are determined for analysis are: corruption index and bribery costs. Then, regression model (or equation) that are used for data analysis is as below:

$$
\operatorname{Ln}(B E t)=\beta 0+\beta 1 \ln (C I t)+\beta 2 \ln (B C t)+\varepsilon t
$$

where the main variables for analyses are as following:

* $\quad \mathrm{BE}=$ Business Environment;

* $\quad \mathrm{CI}=$ Corruption Index;

* $\quad \mathrm{BC}=$ Bribery Costs; 
* $\quad \varepsilon \mathrm{t}=$ Standard Error;

* $\quad \beta 0, \beta 1, \beta 2$, are included in the analysis parameters;

\section{EMPIRICAL RESULTS}

Our main results are based in three methods (linear regression, descriptive statistic and correlation) and interpretations of their results are explained in empirical results. The most important method in our analysis is linear regression method, it is define as the statistical technique that may applied for single or multiple explanatory variable(s) that have been appropriately coded, (Hutcheson, 2011). In linear regression method are presented three analyses: institutions, law and corruption with different variables. In the first analysis is between business environment (as dependent variable) and variables of institutions, such as: political stability and business policies (as independent variables). The results have shown that political stability $(\beta 1=-4.33)$ has negative impact in business environment, but business policies $(\beta 2=8.25)$ has shown positive impact in Kosovo business environment. Despite of reforms in indicators of business climate, Kosovo has been accompanied with unstable in government institutions particularly in last two years. Then, the results in t-statistic analysis ( $\mathrm{T}$ $<2$ ) have shown that both variables of institutions (political stability 0.72 and business policies 0.92) have shown non-significance in business environment. The coefficient of determination $\left(\mathrm{R}^{2}=0.29\right)$ has shown very low relations between institutions variables and business environment in Kosovo (see result in table 1/B).

Table 2/A Test of Linear Regression Method

\begin{tabular}{|l|c|c|c|c|c|c|}
\hline & $\begin{array}{c}\text { Coefficien } \\
\mathrm{t}\end{array}$ & Std. Err. & $\mathrm{T}$-Stat. & $\mathrm{P}>\mathrm{t}$ & {$[95 \%$ Conf } & Interval] \\
\hline $\begin{array}{c}\text { Business } \\
\text { Environment }\end{array}$ & & & & & & \\
\hline Political Stability & -4.334 & 10.390 & -0.42 & 0.72 & -49.040 & 40.371 \\
\hline Business Policies & 9.223 & 80.941 & 0.11 & 0.92 & -339.037 & 357.483 \\
\hline Constant & 57.050 & 6.285 & 9.08 & 0.01 & 30.007 & 84.093 \\
\hline $\begin{array}{c}\text { Business } \\
\text { Environment }\end{array}$ & -4.570 & 9.267 & -0.49 & 0.67 & -44.445 & 35.304 \\
\hline Role of Law & 0.230 & 0.066 & 3.48 & 0.07 & -0.054 & 0.515 \\
\hline Protecting Investors & 52.369 & 7.409 & 7.07 & 0.02 & 20.490 & 84.248 \\
\hline Constant & & & & & & \\
\hline $\begin{array}{c}\text { Business } \\
\text { Environment }\end{array}$ & 0.280 & 0.006 & 42.28 & 0.01 & 0.196 & 0.364 \\
\hline Corruption Index & 0.325 & 0.019 & 16.32 & 0.04 & 0.072 & 0.579 \\
\hline Bribery Costs & 38.329 & 1.043 & 36.74 & 0.02 & 25.073 & 51.585 \\
\hline Constant & & & & & & \\
\hline So
\end{tabular}

Source: Authors estimations 
Zogjani, J., Mazelliu, M., Humolli, B., Qehja, V., \& Kunushevci, A. (2017). The impact of institutions, law and corruption in business environment Evidence for Kosovo. Advances in Social Sciences Research Journal, 4(3) 34-46.

Table 2/B Test of Linear Regression Method

\begin{tabular}{|l|c|c|c|c|c|c|}
\hline Equation & Observation & $\mathrm{F}(3,1)$ & Prob $>$ F & "R-sq" & Adj R-sq & Root MSE \\
\hline Political Stability & 5 & 0.41 & 0.707 & 0.29 & -0.41 & 4.950 \\
\hline Law & 5 & 41.27 & 0.024 & 0.98 & 0.953 & 0.905 \\
\hline Corruption & 4 & 893.99 & 0.024 & 0.99 & 0.998 & 0.160 \\
\hline
\end{tabular}

Source: Authors estimations

In second analysis of linear regression method is included business environment in Kosovo and variables of law, such as: role of law and protecting investors. The results have shown that role of law $(\beta 3=-4.57)$ has negative impact in business environment whereas protecting investors $(\beta 4=0.23)$ have positive impact in Kosovo business environment and it is as results that Kosovo's institutions have made reforms in business climate indicators in recent years. In t-statistic analysis $(\mathrm{T}<2)$ both variables of law are non - significance in business environment. The coefficient of determination $\left(\mathrm{R}^{2}\right)$ is higher, if compare with institutions analysis and relations between both variables of law and business environment in Kosovo is very strong $\left(\mathrm{R}^{2}\right.$ = 98). The third analysis of linear regression method has included the corruption variables (corruption index and bribery) and business environment In Kosovo. The results have shown that both variables of corruption (corruption index $\beta 5=0.28$ and bribery costs $\beta 6=0.32$ ) have shown positive impact in Kosovo business environment. It is due that corruption is determined as the main obstacle in Kosovo business climate and it is very widespread in Kosovo business environment. In T-statistic analysis $(\mathrm{T}<2)$ both variables of corruption are non-significance $(\mathrm{T}$ $<2)$ in business environment whereas the coefficient of determination $\left(R^{2}=0.99\right)$ has the highest rate than institutions and law.

The purpose of descriptive statistical method is to describe the data (through different ways) in analysis, (Miles, 2007). Descriptive statistical method includes variables of institutions, law and corruption in business environment in Kosovo and every variable in analysis have 5 observations (except variables of bribery). Interpretations of results in variables of institutions (political stability and business policies) are as following: political stability in the all analysis of descriptive statistic method has the higher value than business policies, but in the same method both variables of institutions (political stability and business policies) have the lowest rate than business environment. In the second analysis about law in Kosovo business environment are the following results: protecting investors in all analysis of descriptive statistics methods have shown the higher rate than role of law in Kosovo. In the third analysis of corruption and business environment in Kosovo, the variable of corruption index has the higher rate only in standard deviation than bribery costs (also than business environment), but in other analysis (minimum, mean and maximum) bribery costs have achieved the higher rate than corruption index (but in the three analyses, bribery costs have shown lower rate than business environment). 
Table 3 Descriptive Statistics Method

\begin{tabular}{|l|c|c|c|c|c|}
\hline \multicolumn{1}{|c|}{ Variable: } & Observations & Std. Dev. & Min & Mean & Max \\
\hline Business Environment & 5 & 4.16 & 55.71 & 60.11 & 64.76 \\
\hline Political Stability & 5 & 0.69 & -1.13 & -0.77 & 0.47 \\
\hline Business Policies & 5 & 0.09 & -0.12 & -0.03 & 0.12 \\
\hline \multicolumn{1}{|c|}{ Variable: } & Observations & Std. Dev. & Min & Mean & Max \\
\hline Business Environment & 5 & 4.16 & 55.71 & 60.11 & 64.76 \\
\hline Role of Law & 5 & 0.11 & 0.38 & 0.51 & 0.61 \\
\hline Protecting Investors & 5 & 15.82 & 26.67 & 43.67 & 57.5 \\
\hline \multicolumn{1}{|c|}{ Variable: } & Observations & Std. Dev. & Min & Mean & Max \\
\hline Business Environment & 5 & 4.16 & 55.71 & 60.1 & 64.8 \\
\hline Corruption Index & 5 & 16.70 & 2.8 & 21.1 & 34.0 \\
\hline Bribery Costs & 4 & 5.17 & 41.5 & 48.1 & 53.0 \\
\hline
\end{tabular}

Source: Authors estimations

The last method in our research paper is correlation method, and correlation provides the basis for all classical multivariate techniques in linear research methods, (Friendly, M., 2002). The key results in correlation method are divided into three analyses. In the first correlation analysis between variables of institutions (such as: political stability and business policies) and business environment is shown that both variables (political stability and business policies) have negative correlation with Kosovo business environment. In second analysis of correlation is between law and business environment, and results are appeared in two extreme: role of law has a high negative correlation with business environment whereas variable of protecting investors have nearly perfect correlation with business environment in Kosovo. The last analysis of correlation is between corruption variables (corruption index and bribery costs) and business environment. The variable of corruption index has high positive correlation with business environment, but bribery costs and business environment in Kosovo do not have any correlation (because their result is too closely 0 ).

Table 4 Correlation Method

\begin{tabular}{|l|c|c|c|}
\hline \multicolumn{1}{|c|}{ Variables: } & Business Environment & Political Stability & Business Policies \\
\hline Business Environment & 1.00 & & \\
\hline Political Stability & -0.54 & 1.00 & 1.00 \\
\hline Business Policies & -0.48 & 0.94 & Protecting Investors \\
\hline \multicolumn{1}{|c|}{ Variables: } & Business Environment & Role of Law & \\
\hline Business Environment & 1.00 & & 1.00 \\
\hline Role of Law & -0.91 & -0.90 & Bribery Costs \\
\hline Protecting Investors & 0.97 & Corruption Index & \\
\hline \multicolumn{1}{|c|}{ Variables: } & Business Environment & & 1.00 \\
\hline Business Environment & 1.00 & 1.00 & -0.40 \\
\hline Corruption Index & 0.92 & -0.02 & \\
\hline Bribery Costs & & & \\
\hline
\end{tabular}

Source: Author estimations 


\section{CONCLUSION}

Business environment in transition economies (included Kosovo) always is challenged with difficulties from different factors, such as: political stability, role of law, and impact of corruption. Over the past few years, Kosovo has made reforms in business environment (particularly starting a business, construction permits, protecting investors, etc) and these reforms immediately have their impact in business environment and Kosovo has improved significantly their position in global ranking. However, the results of analysis for business environment in Kosovo are divided separately with different variables of institutions, law and corruption. In the first analysis (of OLS method), we can conclude that political stability has negative impact in business environment while business policies have positive impact in Kosovo business environment. Then, role of law (as first variable of law) has negative impact in business environment, but protecting of investors (as second variable of law) have shown positive impact in Kosovo business environment. In the third analysis, both variables of corruption (corruption and bribery) have positive impact in Kosovo business environment. Then, in t-statistic analysis $(\mathrm{T}<2)$ of OLS method all independent variables are nonsignificance on dependent variable (institutions, law and corruption) and institutions have the lowest rate of coefficient of determination $\left(\mathrm{R}^{2}\right)$, but law and corruption have high rate of determination $\left(\mathrm{R}^{2}\right)$. In conclusion, Kosovo constantly have to make reforms and to promote attractive environment for business sector (particularly on SME sector). Then, Kosovo needs to strengthen its institutions (to prevent corruption and nepotism) and to improve their basic infrastructure for business climate (telecommunication, energy, trade barriers, etc).

\section{References}

Agee, J. (2009). Developing qualitative research questions: a reflective process, 22 (4). International Journal of Qualitative Studies in Education , 431 - 447.

Alfen, H. W. (2003). Public-Private Partnership in Infrastructure Development. Scientific series of Chair Construction Economics .

Anderson, J. E. \& Shimul, Sh. N. (2013). Obstacles to Business Operations in Transition Countries: Comparative Analysis of Obstacles Reported in the 2009 BEEPS Data. Social Science Research Network (SSRN) , $1-25$.

Anderson, J.H \& Gray, Ch. W. (2007). Transforming Judicial Systems in Europe and Central Asia. Washington D.C: IBRD \& World Bank.

Ballout, H. (2009). Career Commitment and Career Success: Moderating Role of Self-Efficacy. Career Development International , 14 (7), 655--670.

Budak, J. \& Rajh, E. (2011). Corruption as an Obstacle for Doing Business in the Western Balkans: A Business Sector Perspective. EIZ Working Papers 1109. Zagreb: Economic Institute in Zagreb (EIZ).

Burgess, C., \& Curry, M. (2014). Transforming the health care environment collaborative. AORN Journal , 99 (4), 529-539.

Campbell, D. \& Campbell, Sh. (2008). Introduction to Regression / Data Analysis. New Haven (Connecticut): StatLab Workshop Series 2008 .

Colverson, S. (2012). Public-Private Partnerships The role of hybrid financing strategies in sustainable development.

Council of Europe Report. (2016). The situation in Kosovo* and the role of the Council of Europe, Doc. 13939. Brussels: Council of Europe: Committee on Political Affairs and Democracy. 
Department of Finance, I. (2006). Partnerships: Procedures for the Assessment, Approval, Audit and Procurement of Projects".

Džafić, Z. (2014). Business Enviroment - the case of Western Balkan Countries. Economic Review Journal of Economics and Business, 12 (2) , 73 - 89.

EB Report. (2013). Investment Climate Statement 2013 - Openness to Foreign Investment. Washington D.C: The Office of the Bureau of Economic and Business Affairs (EB) - The U.S. State Department.

EBRD Report. (2011). Strategy for Kosovo: As approved by the Board of Directors at its meeting on 1 May 2013. Washington D.C: EBRD \& The World Bank.

EC Report. (2014). Kosovo* Progress Report 2014: Summary of findings of the 2014 Progress Report on Kosovo. Brussels: European Commission: Department of Enlargement Policy (Publications).

Esser, I., \& Olsen, K. (2011). Perceived Job Quality: Autonomy and Job Security within a Mulitlevel Framework. European Sociological Review , 28 (4), 443--454.

Esther Cheung. (2008). Reasons for implementing public private partnership. Journal of Property Investment and Finance .

Estrin et al. (2005). Entrepreneurship in Transition Economies. In C. e. al, The Oxford Handbook of Entrepreneurship (pp. 1 - 47). Oxford University Press.

Fankhauser, S. (2005). Doing business in transition countries. London: EBRD: Publication Office.

Fletcher, M., Morrison, M., Giles, D., \& Kedian, J. (2016). Leadership development as a dialogic process the rationale and concept of an international leadership institute. International Journal of Leadership in Education , 19 (2), 182-202.

Friendly, M. (2002). Corrgrams: Exploratory displays for correlation matrices. The American Statistician , 1 - 16.

Fu, J., \& Chen, J. (2015). Career Commitment of Information Technology Professionals: The Investment Model Perspective. Information \& Management, 52 (5), 537--549.

Garrison, D., \& Vaughan, N. (2012). Institutional change and leadership associated with blended learning innovation: Two case studies. Internet and Higher Education , 18, 24-28.

Grandy, G., \& Holton, J. (2013). Leadership development needs assessment in healthcare: a. Leadership \& Organization Development Journal , 34 (5), 427-445.

Gross, P. (2012). A Q methodology analysis of individual perspectives of public decision making inflluences of collaborative processes. UMI Dissertation Publishing .

Hollander, J. (2011). Approaching an ideal: using technology to apply collaborative rationality to urban planning processes. Planning Practice and Research , 26 (5), 587-596.

Hurst, C. C., \& Reeves, E. E. (2000). An economic analysis of Ireland's first Public Private Partnership. The International Journal of Public Private Partnership , pp. 379-388.

Hutcheson, G. D. (2011). Ordinary Least-Squares Regression. In L. Moutinho and G. D. In I. L. Hutcheson, The SAGE Dictionary of Quantitative Management Research, 224-228.

IMF Report. (2015). Regional Economic Issues: Special Report. The Western Balkans 15 Years of Economic Transition. Washington, D.C: IMF: Publication Services. 
Zogjani, J., Mazelliu, M., Humolli, B., Qehja, V., \& Kunushevci, A. (2017). The impact of institutions, law and corruption in business environment Evidence for Kosovo. Advances in Social Sciences Research Journal, 4(3) 34-46.

Innes, J. (2016). Collaborative rationality for planning practice. The town planning review , 84 (1), 1-4. Innes, J., \& Booher, D. (2010). Planning with complexity: An introduction to collaborative rationality for public policy. Milton Park: Routledge.

Jäppinen, A. (2013). Co-dynamics in engineering innovations through collaborative leadeship - a complexity-based approach. In R. Smeds, \& O. Irrmann (Ed.), CO-CREATE 2013 : The Boundary-Crossing Conference on Co-Design in Innovation (pp. 225-236). Helsinki: Aalto University Publication Series.

Jamali, D. (2007). A study of customer satisfaction in the context of a public private partnership. International Journal of Quality \& Reliability Management , 370-385.

John, A. A., \& Janssen, M. M. (2010). Public-private partnerships,outsourcing or shared service centres. Transforming Government: People,Process and Policy , 232-248.

Judge, T., Cable, D., Boudreau, J., \& Brets, R. (1995). An Empirical Investigation of the Predictors of Executive Career Success. Personnel Psychology , 48 (3), 485--519.

Keynes, J. M. (2007). Adding value of public private partnership.

Khuntia, J., Karimi, J., Tanniru, M., \& Meyers, A. (2014). The University of Colarado digital health consortium inititative: a collaborative model of education, research and service. Journal of Commmercial Biotechnology , 20 (3), 31-37.

Kinyanjui. (2012). Food Processing \& Technology.

Kothari, C. (2004). Research Methodology: Methods and Techniques (2nd ed.). New Delhi: New Age International Ltd.

Kramer, M., \& Crespy, D. (2011). Communicating collaborative leadership. The Leadership Quarterly , 22, 1024-1037.

Kumar, S., Kant, S., \& Amburgey, T. (2007). Public Agencies and Collaborative Management Approaches. 39 (5), 569-611.

Lavric, M., \& Flere, S. (2010). Measuring Religious Costs and Rewards in a Cross-Cultural Perspective. Rationality and Society , 22 (2), 223--236.

Mazutis, D., \& Slawinski, N. (2007). The art of conversation: how authentic leaders influence organizational learning. Proceedings of OLKC 2007 - "Learning Fusion", 4, pp. 662-675.

McCovery, J., \& Matusitz, J. (2014). Assessment of collaboration in U.S. health care delivery: a perspective from systems theory. Social Work in Public Health , 29 (5), 451-461.

Miles, J. (2007). Descriptive Statistics (Chapter 2). In J. \&. Miles, Understanding and using statistics in Psychology - A Practical Introduction (pp. 11 - 51). London: SAGE Publication Ltd.

Millones, G. M. (2010). Breaking Down Factors of Public-Private Partnership in Urban Rail.

MTI Report. (2011). Development Strategy of SMEs in Kosovo (2012 - 2016) - Vision 2020. Prishtina: MTI: Publication Services.

OECD Report. (2013). Assessment of the Kosovo* Innovation System. Paris: OECD Investment Compact for SEE countries.

Phillips, E.M. \& Pugh, D.S. (2005). How to get PhD: A handbook for students and their supervisors (4the ed). Berkshire, England: Open University Press: McGraw-Hill Education. 
Pruijt, H., \& Derogee, P. (2010). Employability and Job Security, Friends or Foes? The Paradoxical Reception of Employacurity in the Netherlands. Sociao-Economic Review , 8 (3), 437--460.

Raelin, J. (2014). Imagine there are no leaders: Reframing leadership as collaborative agency. Leadership , 0 (0), 1-28.

Raelin, J. (2012). The manager as facilitator of dialogue. Organization , 20 (6), 818-839.

Rajasekar et al. (2006). Research Methodology. Cornell University Library (arXiv.org) , 1 - 53.

Rande, S., Rahawarin, Y., \& Zacharias, T. (2015). Factors Affecting the Career Development of Employees in Secretariate Office of City Samarinda. International Journal of Scientific \& Technology Research , 4 (3).

Roaf et al. (2013). 25 Years of Transition: Post-Communist Europe and the IMF: Regional Economic Issues Special Report. Washington, D.C: IMF: Publication Service.

Roumboutsos, A. R., \& Chiara, N. N. (2002). A strategic partnering framework analysis methodology for Public private Partnership. Journal of Financial Management of Poverty and Construction , pp. 235-246.

Shrimali, B., Luginbuhl, J., Malin, C., Flournoy, R., \& Siegel, A. (2014). The building blocks collaborative: advancing a life course approach to health equity through multi-sector collaboration. Maternal Child Health Journal , 18, 373-379.

Spurk, D., \& Abele, A. (2014). Synchronous and Time-Lagged Effects between Occupational Self-Efficacy and Objective and Subjective Career Success: Findings from a Four-Wave and 9-year Longitudinal Study. Journal of Vocational Behavior , 84 (2), 119--132.

Steves et al. (2004). The Business Environment inthe CIS-7 Countries . Washington D.C: The World Bank \& EBRD.

Stoffers, J., \& Canisius, E. (2015). Differentiated Rewards as an Enticement to Display and Develop more Professionalism in Higher Professional Education-Perceptions of Justice among the Lecture Staff. JHRSS , 3 (2), 57--65.

Taylor, H., \& Morse, R. (2013). Collaborative leadership development for local government officials: exploring competencies and program impact. Public Administration Quarterly , 37 (1), 72-103.

Thorkildsen, A., \& Ekman, M. (2013). The complexity of becoming collaborative planning and cultural heritage. Journal of Cultural Heritage Management and Sustainable Development, 3 (2), 148-162.

Tieman. (2003). public private partnership. Management and Economics through public private partnership .

Tomkins, A., \& Ogloff, J. (1990). Training and Career Options in Psychology and Law. Behav. Sci. , 8 (3), 205--216.

Ugboro, I., \& Obeng, K. (2015). The Moderating Effects of Perceived Threat to Valued Job Features on Career Commitment Among University Professors. Australian Journal of Career Development , 24 (1), 39$-52$.

VanVactor, J. (2012). Collaborative leadership model in the management of health care. Journal of Business Research , 65, 555-561.

Virtanen, M., Kivimaki, M., Virtanen, P., Elovainio, M., \& Vahtera, J. (2003). Disparity in Occupational Training and Career Planning between Contingent and Permanent Employees. European Journal of Work and Organizational Psychology, 12 (1), 19--36. 
Zogjani, J., Mazelliu, M., Humolli, B., Qehja, V., \& Kunushevci, A. (2017). The impact of institutions, law and corruption in business environment Evidence for Kosovo. Advances in Social Sciences Research Journal, 4(3) 34-46.

Wilson, D. I., Pelham, N. N., \& Duffield, C. F. (2010). A review of Australian PPP governance structures. Journal of Financial Management of Property and Construction, 98-215.

World Bank Report. (2012). Business Environment Snapshot for Kosovo. Washington D.C: World Bank: Publication Office.

World Bank Report. (2013). Doing Business 2014: Understanding Regulations for Small and Medium-Size Enterprises. Washington D.C: International Bank for Reconstruction and Development / The World Bank.

World Bank Report. (2014). Doing Business 2015: Going Beyond Efficiency - Economy Profile 2015, No. 92059 (12th ed.). Washington D.C: The International Bank for Reconstruction and Development / The World Bank.

World Bank Report. (2016). Doing Business 2016 - Measuring Regulatory Quality and Efficiency, (13th ed.). Washington D.C: The International Bank for Reconstruction and Development / The World Bank.

World Bank Report. (2016). Doing Business 2016: Measuring Regulatory Quality and Efficiency.

Washington D.C: The World Bank Group.

World Bank Report. (2011). Republic of Kosovo, Country Profile 2013 - Enterprice Surveys. Washington D.C: The World Bank / The International Bank for Reconstruction and Development.

World Bank Report. (2015). The World Bank Group: Country Snapshot. Washington D.C: World Bank: Publication Office.

Yang, F., \& Lau, V. (2015). Does Workplace Guanxi Matter to Hotel Career Success? International Journal of Hospitality Management, 47, 43--53.

Yu, M., \& Lee, M. (2015). Managers' Career Development Recognition in Taiwanese Companies. Asia Pacific Management Review , 20 (1), 11--17. 